\title{
IMMUNOHISTOCHEMICAL LOCALIZATION OF ENDOCRINE G-CELLS IN THE EPITHELIUM OF THE PARS PYLORICA MUCOSA OF THE CAT AND MOUSE STOMACH
}

\author{
H. CERNÝ, S. MAZANEK and Eva ČERNÁ' \\ Department of Anatomy, Histology and Embryology, 'Department of Pathophysiology, Univer- \\ sity of Veterinary Science, 61242 Brno
}

Received March 13, 1991

\begin{abstract}
Cerný H., S. Mazánek, Eva Černá: Immunohistochemical Localization of Endocrine G-Cells in the Epithelium of the Pars pylorica Mucosa of the Cat and Mouse Stomach. Acta vet. Brno, 60, 1991: 317-322.

Tissue samples obtained from the pyloric part (antrum pyloricum) of the stomach of 6 mice and 4 adult cats were fixed in Bouin's solution, embedded in paraplast and sectioned at 5 to $7 \mu \mathrm{m}$.

Endocrine G-Cells were demonstrated in the sections immunohistochemically using a MILAB-ICC kit for immunohistochemical demonstration of gastrin. The final colour visualization was achieved by the binding of the PAP complex.

The study of the distribution, cytomorphology and G-cell types in the epithelium of the mucosa and glands yielded the following results:

1. Endocrine G-cells were scattered diffusely in the basal part of the mucosa.

2. In the cat they occupied the lower half of the height of the mucosal epithelium, in the mouse they were bound topographically to the basal quarter or fifth of the total height of the mucosal epithelium.

3. In both species the surface cells were immunopositive; positive reactions were observed locally also in non-cellular structures of the mucosal surface.

4. In both species two types (open type and closed type) of endocrine G-cells were found to occur.

5. In both cats and mice open-type G-cells were fewer in number than closed-type cells.

6. Cells with polymorphic cytoplasmic projections were observed in both species, but more frequently in the mouse than in the cat.
\end{abstract}

Gastric mucosa, pars pylorica, G-cell, immunohistochemistry, cat, mouse

Cells synthesizing and secreting bioactive peptide hormones are scattered diffusely in the epithelium of the gastric and intestinal mucosa from the cardia to the rectum. Entero-endocrine cells constitute a separate endocrine system the hormones of which control or affect locally the functions of the organ. They are involved in a number of processes associated with digestion, secretion of the glands, food absorption and gastric or intestinal motility, and affect the blood flow through the blood vessels and the intensity of the epithelial cell cycle of the digestive system.

Foetal endocrine cells are supposed to function in prenatal ontogeny as pluripotent cells capable of differentiation into one or more types of endocrine cells that at first are of no primary importance to digestion. Because of their biosynthetic functions, however, they are of value to the development and differentiation of the digestive system and pancreas, thus exerting trophic effects of some peptide hormones.

Out of a number of functionally determined endocrine cell types our present study is focused on the demonstration and cell topography of G-cells. The first to demonstrate gastrin was McGuigan (1968). Since in G-cells metachromasia often occurs on the application of silver impreg- 
nation techniques and non-specific reactions are frequently a problem in immunohistochemical studies (Grube 1980), it is essential that the technique used should exclude the possibility of non-specific binding of protein.

Endocrine cells in the epithelium of the mucosa of the digestive system of the rat have been studied by Forssmann et al. (1969) and endocrine cells of the gastrointestinal tract of the cat have been investigated by Kitamura et al. (1982) and Uvnäs-Wallensten (1977).

A considerable increase of the interest in enteroendocrine cells occurred in the seventies and particularly in the eighties. In addition to investigations concerning their histotopographic demonstration and cellular morphology a number of studies have been reported on the mechanisms and control of secretion including the action and characteristics of individual peptide hormones. Among the data published along this line mention should be made at least of those reported by Fujita (1976), Lechago and Barajas (1981), Uvnäs-Wallensten (1977), Grube and Forssmann (1979), Grube $(1980,1986)$ and S tern berger (1986).

More recent studies (Grube 1986) admit even the possibility of exocrine secretion and direct secretion of peptides to the gastric or intestinal lumen.

\section{Materials and Methods}

Specimen of the pyloric mucosa obtained from the antrum pyloricum of 6 mice (Mus musculus v, alba) nad 4 adult cats (Felis domestica) were fixed in Bouin's solution, embedded in paraplast and sectioned at 5 to $7 \mu \mathrm{m}$.

Gastrin-producing cells were demonstrated in the sections immunohistochemically using a MILAB ICC kit (Immunochemistry of Neurohormonal Peptides, MILAB, Malmö, Sweden) for immunohistochemical demonstration of gastrin.

The kit is designed for routine immunohistochemical diagnosis. In contains all necessary reagents and optimum-diluted antisera, and makes possible to inhibit endogenous peroxidase activity in the tissues and to block non-specific binding of protein.

The final colour visualization of the cells is made possible by the PAP complex binding of peroxidase-labelled antibodies.

\section{Results}

As to the tissue topography, G-cells were seen particularly in the glands and their ducts and in the epithelium of the pyloric mucosa in the antrum pyloricum region. Their immunopositivity was manifested by dark-brown staining which differentiated them from the adjacent epithelial cells. Endocrine cells were scattered diffusely mainly in the basal part of the mucosa where the pyloric glands are situated. In the cat, they occupied as much as a half of the height of the mucosal epithelium. In the upper half of the mucosa, on the other hand, they were present only sporadically.

Of interest was the finding in the gastric lumen of immunopositivity of the mucosal surface and also of non-cellular structures covering the mucosal surface in the form of mucus.

In.mice the distribution of endocrine G-cells in the epithelium of the antral pyloric mucosa was somewhat different: G-cells were found to occupy the basal quarter or fifth of the total height of the mucosal epithelium and were almost absent from its medium and upper parts.

The surface of the mucosal epithelium of the mouse showed marked immunopositivity manifested by a continuous staining zone on the mucosal surface.

Endocrine cells were located, for the most part, basally, their apical pole being masked with adjacent epithelial cells of non-endocrine character. Also secretory granules were observed in the basal part of endocrine cells, whereas the cytoplasm of the supranuclear part of the cells contained other cellular organelles. 
From the microscopic picture of the mucosa it appears that G-cells occurred in two cell types. One of them was „,closed type “; the other type was different in shape: it was elongated, pear-shaped and had a narrow apical pole extending to the epithelial surface. Although this type of G-cell was located in the basal part of the mucosa or gland tubules, some of these cells were in direct contact with the gastric lumen through their apical ends and were therefore designated as open-type endocrine cells.

In both cats and mice open-type endocrine G-cells were fewer in number than endocrine cells of the closed type.

Also in the gland tubules closed-type endocrine cells predominated over open-type cells.

The basal pole of some endocrine cells exhibited numerous cytoplasmic projections mediating contact with the adjacent cells. Cells having cytoplasmic projections were observed more frequently in the mouse than in the cat. In both animal species these cytomorphologically determined cells were found in the epithelial lining of the pyloric glands (Plates IV., V., VI., Figs. 1-6).

\section{Discussion}

Endocrine cells designated as G-cells secrete the hormone gastrin the tissue activity of which is manifested mainly by local stimulation of the secretion of the gastric glands of the mucosa, by increased motility of the stomach or intestine and by stimulation of the blood flow through the gastric wall.

The present observations are an extension of our previous results (Černý 1988,1989 ) and demonstrate the differences in tissue topography, cytomorphology and cell type determination between the cat and the mouse. The immunohistochemical demonstration of gastrin was made using a MILAB kit (Sweden) for gastrin demonstration with which we have had very good experience.

Since the first immunofluorescent demonstration of gastrin by McGuigan (1968) G-cells have been studied in detail with respect to their distribution, tissue topography, cytomorphology and modes of secretion. Particularly the last-mentioned area has been the subject of numerous investigations. Recent studies have admitted that besides endocrine secretion of these cells there may exist also an exocrine type of secretion with direct secretion to the gastric or intestinal lumen of gastrin as substrate of secretion granules (Grube 1986). Although gastrin, as peptide hormone, has been demonstrated repeatedly in the gastric juice, the mechanism of its transport to the stomach lumen remains unclear from the morphological point of view.

The fact that endocrine G-cells occur in two types has been well-established; the differences in their morphology were pointed out as early as 1976 by Fujita (1976). In recent studies an assumption has been made that the distribution of gastrin occurs by the from-cell-to-cell route in a cell complex arisen by junction of endocrine cells and epithelial cells of non-endocrine character or via direct secretion by „open-type ${ }^{\text {‘6 }}$ endocrine cells at whose apical pole numerous microvilli are produced by the cytoplasmic membrane whereby the luminal contact is increased. With reference to the cell topography and the characteristic cytomorphology it has been suggestd by a number of writers that these cells function as receptors receiving and transmitting stimuli originating in the lumen. The immu- 
nopositivity of the surface epithelial cells supports the theory of intercellular distribution.

On the contrary, in the more frequently occurring endocrine cells referred to as closed-type cells autocrine, endocrine and paracrine secretion has been suggested. The paracrine mode of secretion has been associated with the occurrence of endocrine cells whose basal pole shows numerous cytoplasmic projections that increase the cell surface and may play an important role in transcellular transmission of the peptide hormone - gastrin.

From our observations it appears that these cells do occur in the two species under study, but only to such an extent that does not allow us to ascribe to them a predominant role in the transport of gastrin between cells. According to Larson et al. (1979) the cytoplasmic projections may, in addition to paracrine secretion, act as mediators of the stimuli to adjacent cells. In our view, cytoplasmic projections shoud be studied in a series of consecutive sections to avoid a misinterpretation of the results. Therefore we regard their presence as solitary findings and attach to them no major role from the histophysiological point of view. Apart from paracrine secretion adjacent cells may be stimulated from the blood capillaries as has been reported for S-cells by Wey rauch et al. (1987).

Of particular importance are open-type endocrine cells that in addition to mechanical or autonomic stimulation act as cells with chemoreceptive stimulation. Also in studies concerned with somatostatin-producing cells open-type cells have been detected, being found particularly in the glands of the pyloric portion of the gastric mucosa of the rat (Alumets et al. 1979), cat (Kita mura et al. 1982) and horse (Kitamura at al. 1984). In contrast to the afore-mentioned writers Weyrauch et al. (1987) described them not only in the surface epithelium of the mucosa but also in the basal parts of the pyloric glands. A similar distribution was found by us for G-cells of the antral pyloric mucosa.

\section{Imunohistochemické znázornění endokrinních G-buněk v epitelu sliznice pars pylorica žaludku kočky a myši}

Materiál získaný z pylorické sliznice žaludku 6 myší a 4 koček byl fixován v Bouinově roztoku, zalit do paraplastu a krájen na řezy 5-7 $\mu \mathrm{m}$ tlusté.

Endokrinní G-buňky jsme prokazovali ve tkáňových řezech imunohistochemicky za použití soupravy MILAB-ICC Kit pro imunohistochemický průkaz gastrinu. Konečné barevné vizualizace bylo dosaženo vazbou PAP komplexu.

Popsali jsme distribuci, cytomorfologii a typy G-buněk v epitelu sliznice a žláz $s$ těmito výsledky:

1. Endokrinní G-buñky jsou difúzně rozptýlené v basální části pylorické sliznice.

2. U kočky zaujímají celou spodní polovinu výšky epitelu sliznice, u myši jsou topograficky vázány na basální čtvrtinu nebo pětinu celkové výšky epitelu sliznice.

3. Povrchové bunkky jsou u obou druhů imunopositivní a positivní reakci zachycujeme lokálně i v nebuněčných strukturách na povrchu sliznice.

4. U obou druhů se vyskytují endokrinní G- buňky ve dvou buněčných typech, jako otevřený a uzavřený typ endokrinní buňky.

5. Jak u kočky, tak i myši jsou G-buňky otevřeného typu ve srovnání s uzavřeným typem buněk zastoupeny $\mathrm{v}$ menším počtu.

6. Výskyt buněk $s$ polymorfními cytoplasmatickými výběžky jsme zachytili $u$ obou druhů, $s$ častějším výskytem u myši. 


\section{Иммүногистохимическое изображение эндокринных Г-кпеток В эпителии привратниковой слизистой желүдка кошки и мыши}

Полученный из привратниковой слизистой 6 мышей и 4 кошек материал фиксировали в растворе Буин, заливали в парапласт с послеаующим созданием срезов 5-7 мкм толщиной.

Эндокринные Г-клетки нами были установлены иммуногистохимически в тканевых срезах при применении набора MILAB-ICC Кит для имиуногистохимической идентификации гастрина. Окончательной цветной визуализации было достигнуто связью РАР-комплекса.

Проводиги описание дистрибуции, цитоморфологии и типов Г-Клеток в эпителии слизистой и желез со следующими результатами:

1. Эндокринные Г-клетки диффузионно рассеяны в базальной части привратниковой слизистой.

2. У кошки они занимают всю нижнюю половину высоты эпителия слизистой, у мышей - топографически связаны с базальной одной четвертой или пятой частей общей высоты эпителия слизистой.

3. Поверхностные клетки у обоих видов отличаются иммунопозитивностью, позитивная реакция была установлена локально также в неклеточных структурах на поверхности слизистой.

4. У обоих видов эндокринные Г-клетки встречаются двух типов открытый и закрытый типы эндокринной клетки.

5. У кошек и мышей Г-клетки открытого типа по сравнению с закрыгым типом клеток встречаются в меньшем количестве.

6. Наличие клеток с полиморфными цитоплазматическими отростками было установлено у обоих видов, чаще однако у мышей.

\section{Acknowledgement}

We thank Mrs A. Hloušková and Mrs R. Spěšná for processing the materials for immunohistochemical demonstration and for further technical assistance.

\section{References}

ALUMETS, J.-EKELUND, M.-EL MUNSHID, H. A.-HAKANSON, R.-LOREN, I.: Topography of somatostatin cells in the stomach of the rat. Possible functional significance Cell Tiss. Res., 202, 1979: 177-188

CERNY, H.: Immunohistochemical demonstration of endocrine G-cells in gastric epithelium. Z 1. Vet. Med. C, Anat. Histol. Embryol., 18, 1989: 268

CERNYY, H.: Imunohistochemické znázorněnı́ G-buněk $v$ epitelu sliznice žaludku. Scripta medica, 64, $1991: 49$

FORSSMANN, W. G.-OREI, L.-PICTET, R.-RENOLD, A. E.-ROUILLER, CH.: The endocrine cells in the epithelium of the gastrointestinal mucosa of the rat. J. Cell Biol., 40, 1969: 692-715

FUJITA, T.: The gastro-enteric endocrine cell and its paraneuronic nature. In: Coupland, RE, Fujita, T. (eds) Chromaffin, enterochromaffin, and related cells. Elsevier, Amsterdam, 1976: $191-208$

FUJITA, T. - KOBAYASHI, S.: Structure and function of gut endocrine cells. Int. Rev. Cytol., 6, 1977: $187-233$

GRUBE, D.: Immunoreactivities of gastrin (G-) cells. II. Nonspecific binding of immunoglobulins to G-cells by ionic interactions. Histochemistry, 66, 1980: 149-167

GRUBE, D.: Die endokrinen Zellen des Verdauungsapparats. Klin. Wschr., 60, 1982: 213-277

GRUBE, D.: The endocrine cells of the digestive system: amines, peptides, and modes of action. Anat. Embryol., 175, 1986: 151-162 
GRUBE, D.-FORSSMANN, W. G.: Morphology and function of the enteroendocrine cells. Horm Metab Res., 11, 1979: 589-606

McGUIGAN, Je.: Gastric mucosal intracellular localization of gastrin by immunofluorescence. Gastroenterology, 54, 1968: 1 005-1 011

KITAMURA, N.-YAMADA, I.-YAMASHITA, T.-YANA IHARA, N.: Endocrine cells in the gastrointestinal tract of the cat. Biomed. Res., 3, 1982: 612-622

KITAMURA, N.-YAMADA, I.-CALINGASAN, N. Y.-YAMASHITA, T.: Immunocytochemical distribution of endocrine cells in the gastrointestinal tract of the horse. Equine vet. J., 16, 1984: 103-107

LARSSON, L. I.-GOLTERMANN, N.-De MAGISTRIS, L.-REHFELD, J. F.SCHWARTZ, T. W.: Somatostatin cell processes as pathways for paracrine secretion. Science, 205, 1979: $1393-1394$

LECHAGO, J.-BAJARAS, L.: Innervation of rat antral gastrin-producing cells. Anat. Rec., 200, 1981: 309-313

RIZZOTI, M.-DOMINEGHINI, C.-CASTOLDA, L.: The endocrine cells of the pyloric glands of adult ox. Basic appl. Histochem., 24, 1980: 33-52

STERNBERGER, L. A.: Immunocytochemistry (3rd ed). Wiley, New York, 1986: 523 p.

UVNAS-WALLENSTEN, K.: Occurrence of gastrin in gastric juice, in antral secretion, and in antral perfusates of cats. Gastroenterol, 73, 1977: 487-491

WEYRAUCH, K. D.-BLÄHSER, J.-PORSCHBACHER, J.: Somatostatin Cells in the Gastric Mucosa of Small Ruminants. Immunohistochemical Study. Acta anat., 128, 1987: 188-193 
Plate IV.

Černý H.: Immunohistochemical Localization... pp. 317-322

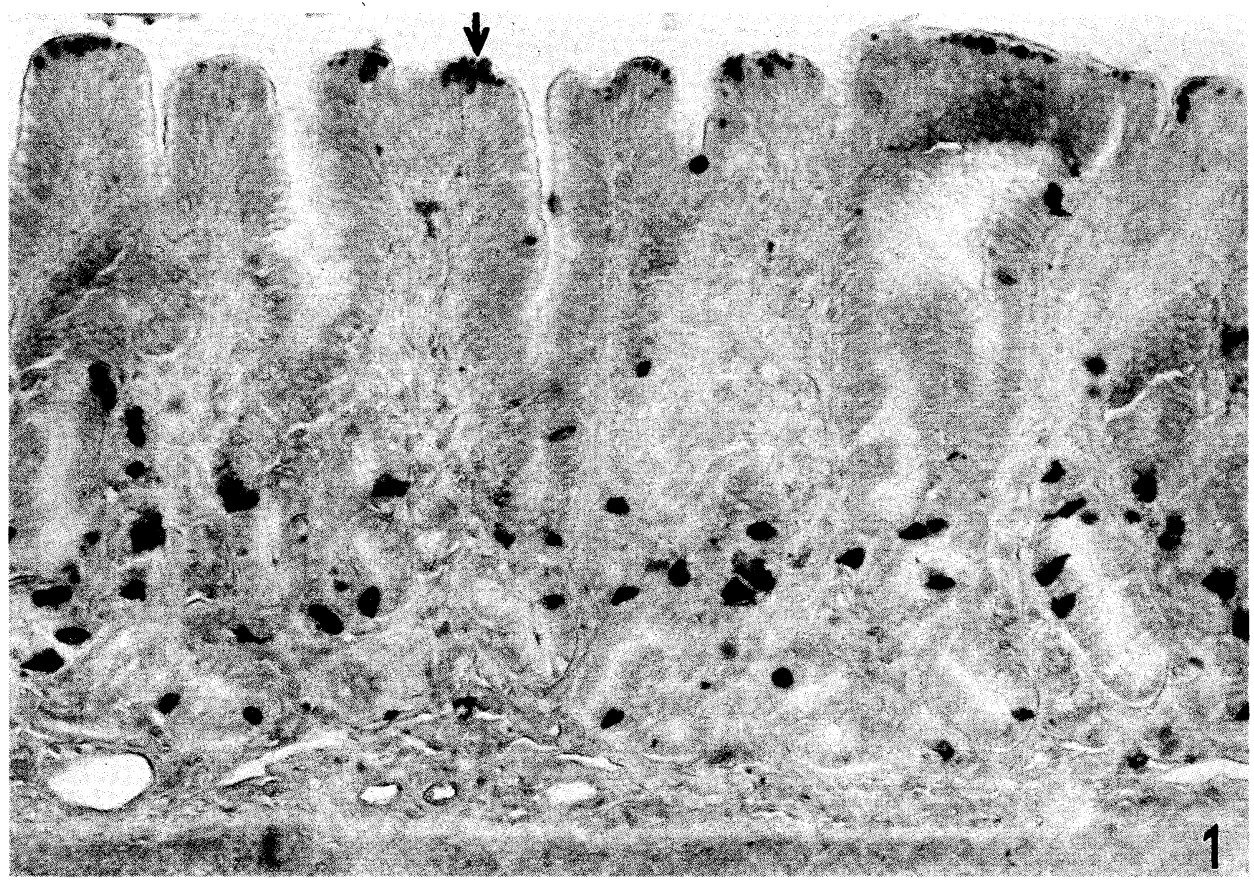

Fig. 1. Distribution of G-cells in the mucosa of the pars pylorica of the cat stomach. The cells occupy the lower half of the height of the mucosal epithelium. Note immunopositivity on the surface of the mucosa. $\times 16 . \times 1.1$.

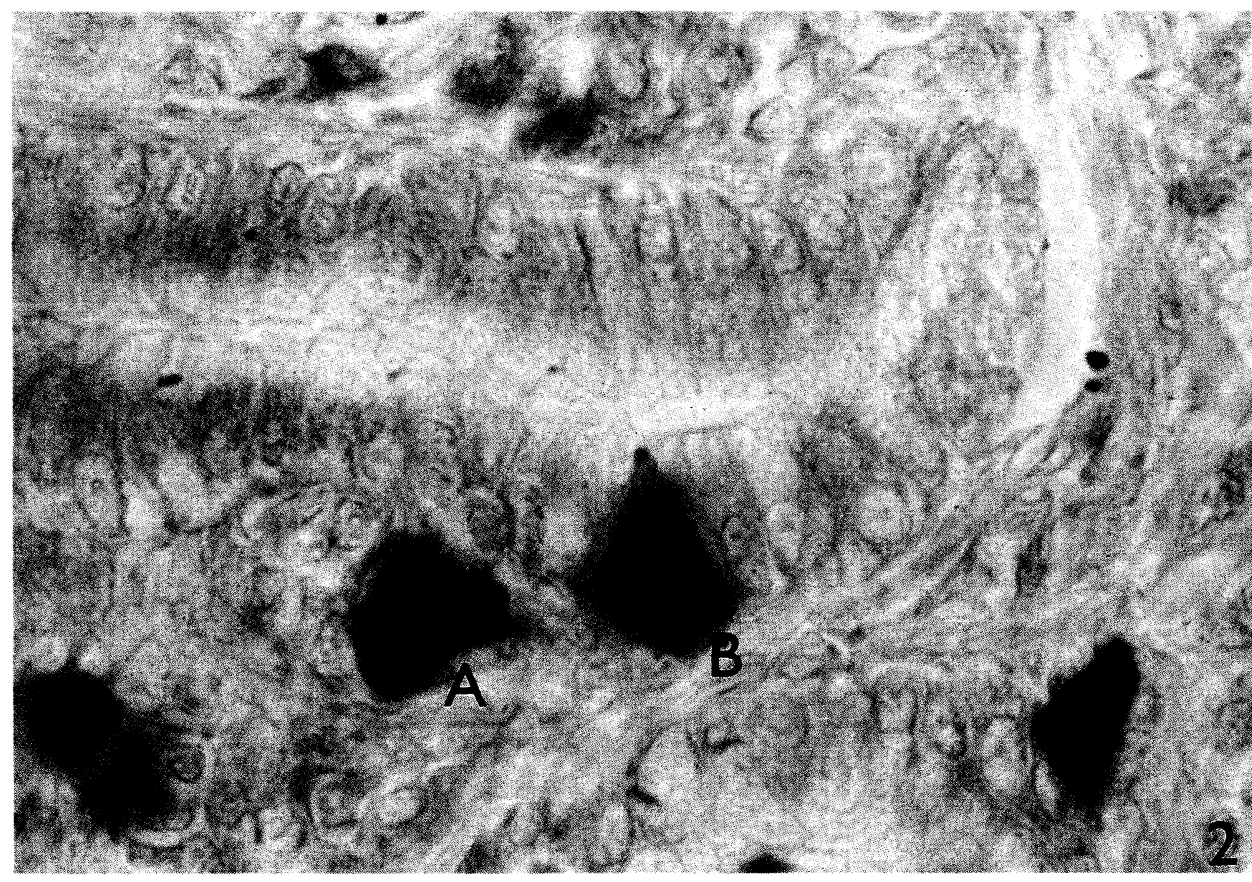

Fig. 2. Closed-type (A) and open-type (B) endocrine G-cells in the epithelium of the pyloric gland tubule of the cat. Apical pole of the open-type endocrine cell is in direct contact with the gland lumen. $\times 100 \times 0.8$. 
Plate V.

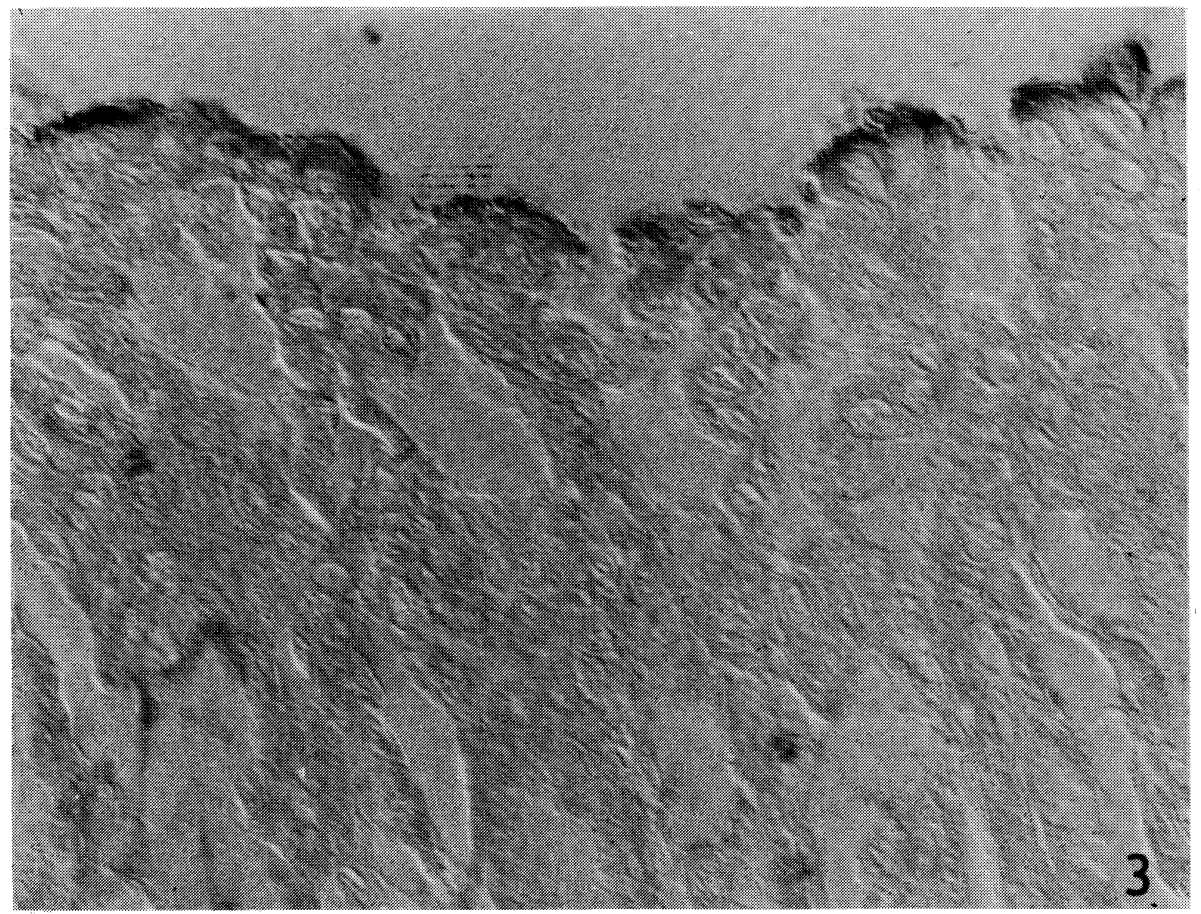

Fig 3. Surface immunopositivity of the pyloric gland of the mouse. $\times 50 \times 10$.

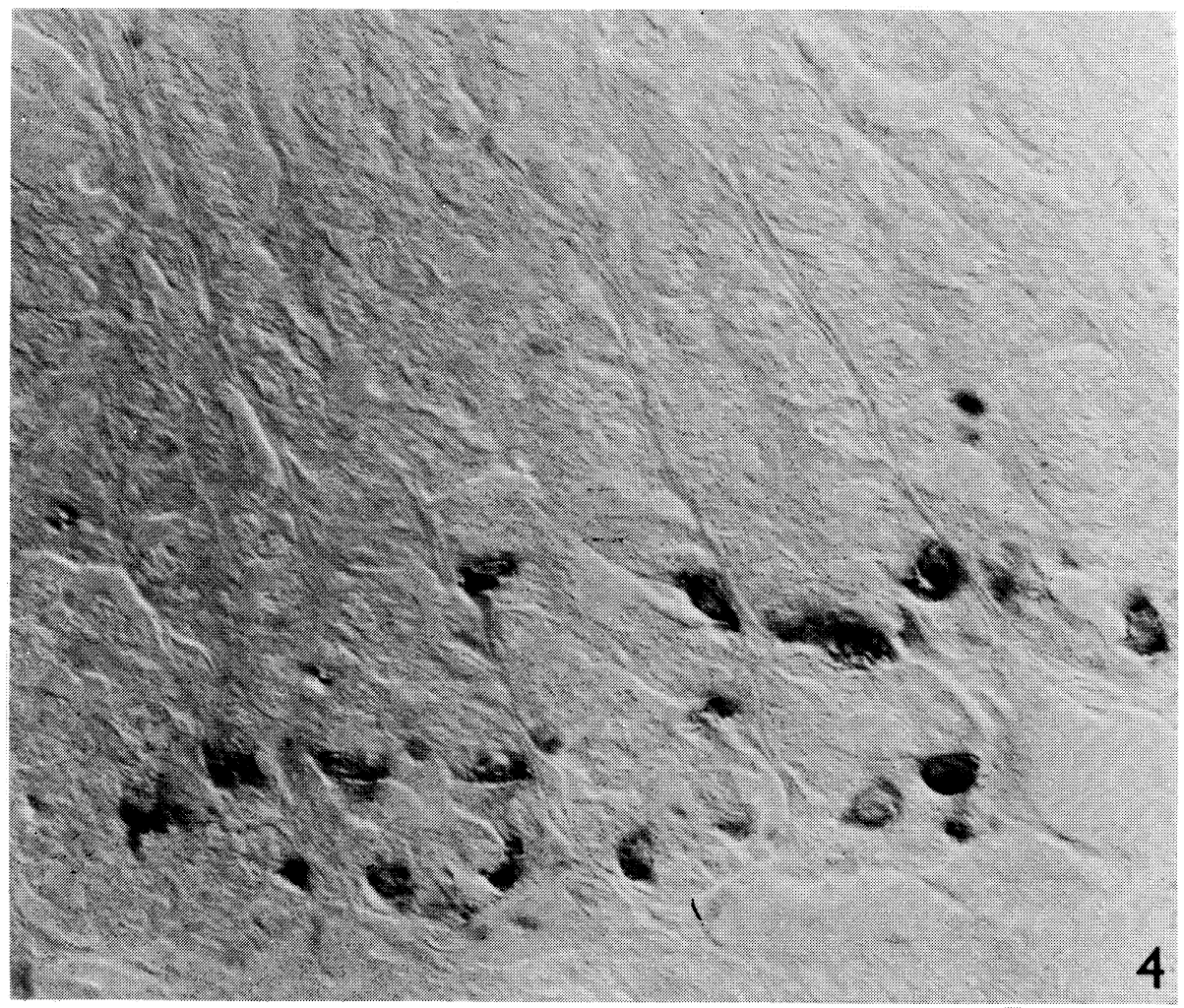

Fig 4. Basal quarter of the total height of the pyloric mucosa of the mouse showing endocrine cells localized mainly in the gland tubules. $\times 50 \times 10$. 
Plate VI.

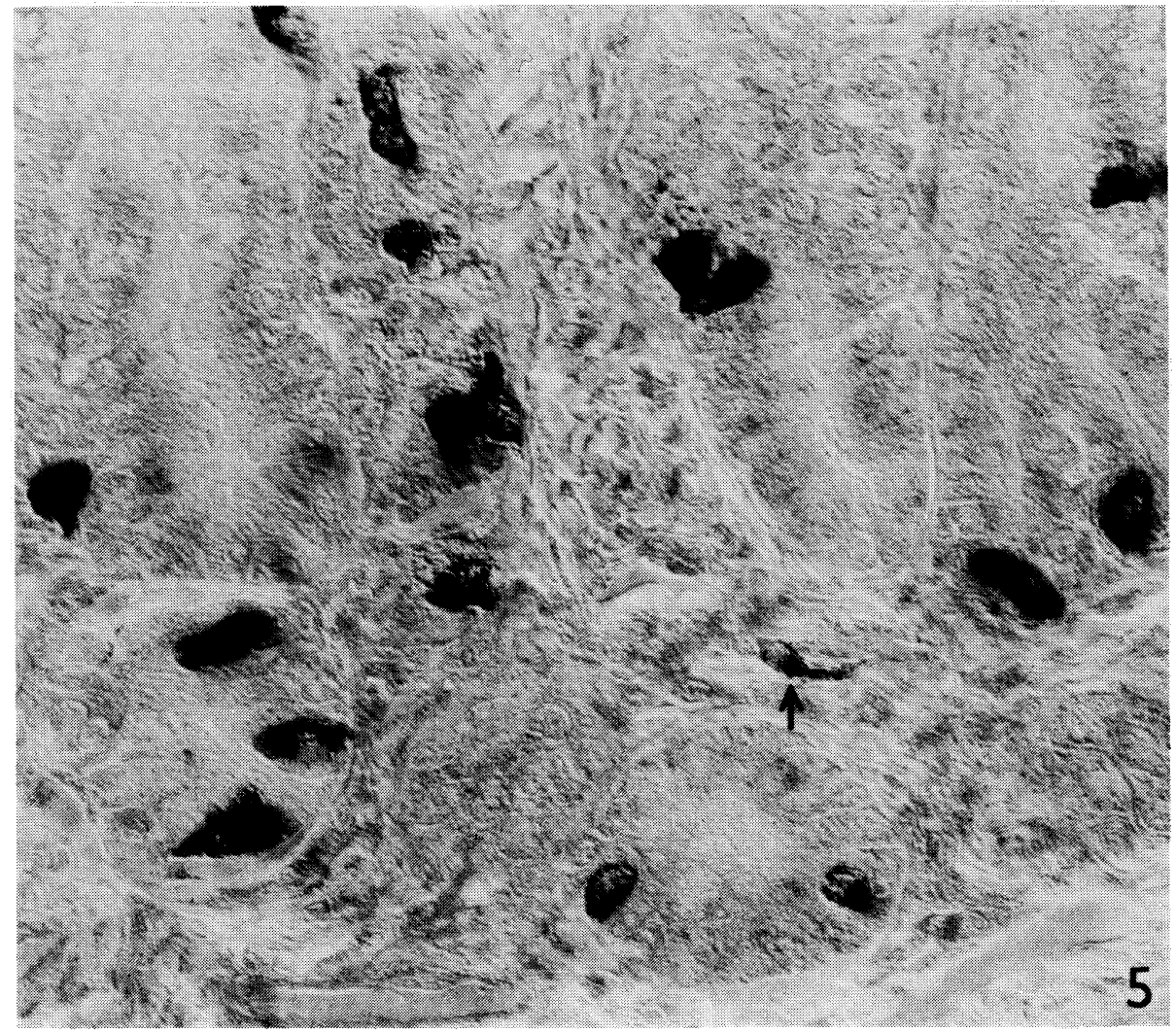

Fig. 5. Endocrine G-cells with polymorphic cytoplasmic projections in the basal part of the pyloric mucosa of the cat. $\times 50 \times 10$.

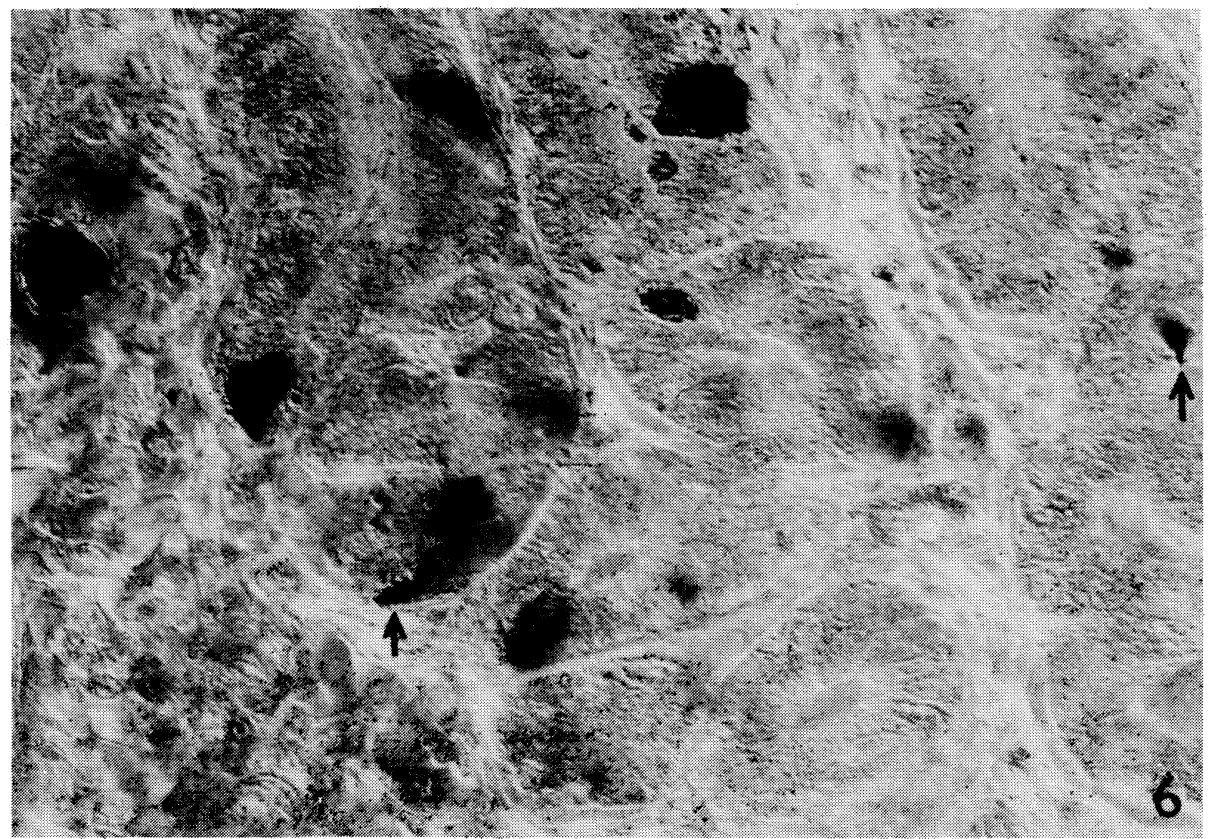

Fig. 6. G-cell with a marked cytoplasmic projection (asterisk) extending to the adjacent cells of the cell complex of the gland tubule of the pyloric mucosa of the cat. $\times 50 \times 10$.

The microphotographs were made using a Zeiss Axiomat photomicroscope at the Anatomical Department of the Veterinary University, Hannover, in personal co-operation with Prof. Dr. R. Schwarz which we gratefuly acknowledge. 